\title{
The Church and Political Transition in Zimbabwe: The Inclusive Government Context
}

\author{
Lawrence Mhandara (Corresponding author) \\ Department of Political and Administrative Studies \\ University of Zimbabwe, Harare \\ Zimbabwe \\ Email:1mhandara@gmail.com
}

Charity Manyeruke

Department of Political and Administrative Studies

University of Zimbabwe, Zimbabwe

Email:nevanjic@gmail.com

Sharon Hofisi

Department of Political and Administrative Studies

University of Zimbabwe, Zimbabwe

Received: January 13, 2013 Accepted: February 27, 2013 DOI: 10.5296/jpag.v3i1.3379

\begin{abstract}
This article explores the role of the church in Zimbabwe's political space with emphasis on the transitional epoch set in motion with the consummation of the Inclusive Government after the signing of the Global Political Agreement on 15 September 2008. Being exploratory in approach, the study preferred a qualitative research design were secondary sources were the major source of data. Departing from the view point that the church and the state are complementary in satisfying human needs, the research established that the church is replete with political activists who are partaking in key political processes envisaged under the transitional phase and the enormity of their participation vary depending on the national issue at hand. More clearly, the church's association with the political parties in the government has been mostly that of a horse-rider relationship where politicians use the church to score cheap political points.
\end{abstract}

Keywords: Church, Political Transition, Zimbabwe 


\section{Introduction}

The turn of the millennium marked the visible onset of Zimbabwe's era of economic and political instability. The defining moment was the February 2000 Constitutional Referendum which broke the ruling party's political preponderance epitomised by the unexpected loss to the opposition, Movement for Democratic Change (MDC). Being the first electoral defeat in the post-independence electoral history, the ruling party was left shocked. As the reality of conceding ground to the opposition became bitter, the ruling Zimbabwe African National Union-Patriotic Front (ZANU-PF) responded through various policies which were politically calculated to regain the lost but vital support indispensable for its political survival. The party, through the government, resorted to the accelerated land reform to win back the rural and peri-urban vote (constituting the majority of the eligible registered voters). To regain the urban vote lost to the MDC, the party reportedly resorted to intimidation, fear and violence against the MDC supporters. The tactics proved politically correct given the performance of ZANU-PF in the subsequent elections serve for the 2008 harmonised elections. The impact of ZANU-PF's policy responses was largely negative for the country's economic and political being. Political polarisation became the order of the day and the peak of the crisis was the June 27, 2008 presidential run-off. The credibility of the successive elections held since the 2000 constitutional referendum was always questioned and contested by the contending political parties prompting the SADC to intervene to resolve the political impasse. The SADC's intervention efforts yielded the Global Political Agreement signed on 15 September 2008 which paved way for the formation of the coalition government inaugurated on 13 February 2009. This marked the transition from ZANU-PF rule to a new era of shared power in Zimbabwe. The Inclusive Government (IG) is a transitional authority because it was mandated to deliver the country from a hurting political stalemate and poor economic performance to a new era.

Since the medieval era the church has been an integral part of the corpus of political life. In Zimbabwe, the church has been active on the political scene on various fronts yet its exact role within the context of this political transition has been least explored. Within this transitional epoch, a number of activities were envisaged including national reconciliation and constitution-making. The article seeks to situate the role and impact of the church within the trajectory of Zimbabwe's politics under the IG. Research indicates that the church is prominent on the radar of political life as evidenced by the activities of the organised Christian networks in Zimbabwe, such as the Zimbabwe Council of Churches (ZCC), the Evangelical Fellowship of Zimbabwe (EFZ) and the Zimbabwe Catholic Bishops' Conference (ZCBC).

\section{The Church and the State: Unpacking the Intellectual Roots}

Attempts to establish the relationship between the church and the state are by no means a new debate is confined to modern political systems. Efforts to establish a relationship between the two institutions are traceable to the era of the disintegration of the Roman Empire around AD400 and to the ascendancy of Christianity as the official religion of that Empire in 310 (Boucher and Kelly, 2009). The church emerged at a time when life in the Empire was 
horrible and disappointing hence it emerged at a time when the society was unhappy and hopeless. The church therefore entered the fray of politics to give hope and happiness to the hopeless and joyless people. In this way, Christianity emerged to challenge secular rulers and secular thinkers who desired to maintain a dichotomy between the politics and the church. In its explanation to the unfortunate conditions that led to the fall of the Roman Empire, the church often found strong reasons to blame the moral corruption of the society. The general Christian belief by then was framed in the understanding that eternal law, which resided in man's heart, enabled people to retain flickering of the ideal of justice that they use to inform their legal, economic and political institutions (Boucher and Kelly, 2009). However, in his thesis, The City of God, St Augustine, one of the prominent Christian political thinkers presented a pessimistic view of politics and political life. He advanced the view that politics is a necessary but indelibly tarnished feature of the human being in his relationship with God. St Augustine, a Manichean who converted to Christianity at the age of 32, characterised politics as belonging to the Earthly City (an imaginary state) which is infested by sinful and lustful people; its political leaders are perceived as corrupt and largely immoral due to the incessant pursuit of their self-interests. The long and short of his political theory is that politics does not serve any useful purpose besides being an arena of lustful individuals disguised as politicians. Augustine however acknowledged that the earth hosts both sinners and the children of God but are only united for the purpose of maintaining peace so as to pursue their respective purposes. This is the position that has been advanced by a number of church leaders in the country who always argue for a peaceful environment.

Yet Augustine's conception of human nature and politics stands in stark contrast with that of St Thomas Aquinas in fundamental ways. Acquinas' political theory effectively brings back the marriage between politics and ethics and by extension the church and the state. Just like the ancient philosophers, especially Aristotle, St Acquinas' political theory regarded politics as good for the purpose of both human happiness and development. St Acquinas effectively recognises that the state and the church are intertwining institutions of the same social reality hence there is only a division of labour between the two since they serve the same purpose, that is, human happiness on earth which is important for his connection to God. He therefore held a positive view of politics as opposed to Augustine's fallacial conjecture that politics is for the evil and the church for the morally good.

Based on these ideas, it is evident that the behaviour of churches significantly draws from the above intellectual foundation. The pertinent question then is where can one situate the church in this transformative phase of Zimbabwe's political corpus? Before a response to this question is presented, it is compelling that a clear background to the transitional arrangement be explored first.

\section{Reasons for the Transitional Arrangement}

In investigating the role of the church in Zimbabwe's political transformation, it is imperative to highlight the key landmarks that yielded the GNU of which a considerable number of authors have extensively written on these defining moments. (Raftopoulos and Savage 2005; Sachikonye Lloyd et. Al, 2007; Masunungure, 2009; Sachikonye, 2011). The turning point in 
the relative political stability that the country had enjoyed since the Unity Accord (1987) between Zimbabwe African National Union (Patriotic Front) [ZANU (PF)] and Patriotic Front-Zimbabwe African People's Union (PF-ZAPU) was the draft constitutional referendum held in February 2000. The outcome of the 2000 referendum, which registered the first electoral defeat for the incumbent party, was succeeded by a period of instability and politically motivated violence in the 2000, 2002, 2005 and 2008 elections. For instance, estimates indicate that between 200 and 500 people were killed during the June 27, 2008 presidential election run-off (Youth Forum, 2010; Media Institute of Southern Africa, 2012). The political conflict was further exacerbated by incessant claims from the opposition movements and their international apologists that the successive elections were marred with inconsistencies and irregularities that were calculated to tilt the result in favour of the incumbent (European Union Observer Report, 2000; Commonwealth Report, 2000 and 2002; SADC Parliamentary Forum, 2002; ZESN Report, 2002; ZESN Report, 2008; Alexander and Tendi, 2008; Makumbe, 2009; Masunungure, 2011).

The use of coercion as the basis of state power was buttressed by a cocktail of legal and institutional instruments which were meant to circumvent the exercise of democratic rights. Some of these include the Access to Information and Protection of Privacy Act (AIPPA) [Chapter 12:01] and the Public Order and Security Act (POSA) [Chapter 11:17] all of which became the major rallying points for the deepening conflict. The conflict was given more impetus by the allegations of militarization of key state institutions epitomised by the appointment of retired high-ranking officers from the uniformed forces to assume tutelage of leading institutions such as the Zimbabwe Electoral Commission (ZEC), Grain Marketing Board (GMB) and National Oil Company of Zimbabwe (NOCZIM). The point of friction with the key military appointments was not only the loyalty of the military to the incumbent party; it also related to the fact that it could not be proven that the appointees were better qualified to hold the appointments than their civilian counter-parts. The appointments were thus seen as part of the patronage that was at the root of the country's decline (Zimbabwe Institute, 2008; Masunungure, 2009). In cases where the opposition parties and their civil society counterparts attempted to challenge the authority of the ruling elites by way of demonstrations, like in the case of the 'final push' of June 2003, marches and 'prayers', such as the one organised by Save Zimbabwe Campaign on 11 March 2007, they were met with equally aggressive and uncompromising response indicating that the ruling party was unprepared to surrender power without a fight. Such responses were however important in the internationalisation of the conflict starting with the Western countries and ending with SADC's involvement.

The key marks on the political scene could hardly shade complete light on the background without a snap survey of the key issues for contest along the economic terrain. The country's political woes coincided with a period of economic misfortune. Although the signs of down-turn were witnessed in the late 1990s as evidenced by widespread workers' strikes and food riots, the rapid collapse of the economy was evident at the turn of the millennium which saw the formal economy under-performing until the adoption of the multi-currency system in February 2009. By October 2008, the country had the fastest shrinking economy in the world 
declining by a 40 per cent margin; it recorded the highest year-on-year inflation rate of over one million per cent (Zimbabwe Institute, 2008; Central Statistical Office, 2009; Chagonda 2012). The impact of the state of the economy on the livelihoods of ordinary citizens was negative: unemployment levels astronomically surged to estimates of over 80 per cent with poverty estimates indicating that 80 per cent of the population lived below the poverty datum line while estimates indicate that a third of the population required some form of food assistance in 2008 (Zimbabwe Institute, 2008). The result of the situation was that an international public opinion survey in 2006 observed that Zimbabweans were amongst the two most unhappy societies in Sub-Saharan Africa as a result of their economic and political conditions (AfroBarometer, 2006). The response of the population to the multi-layered challenges was two-fold: Firstly, most citizens resorted to the informal sector for their livelihood and secondly, the harsh economy pushed a handful of citizens out of the country, mainly into South Africa, Botswana, Namibia, UK, Australia, New Zealand, Canada and the United States of America who hosted an estimated quarter of the country's population (Pasura, 2009).

At the international level, Zimbabwe's conflict received a lot of interest not only because of the aforementioned developments but also because of the contested and poignant circumstances surrounding the land reform exercise. This arises from the observation that the dispossessed white landed gentry was a small but powerful clique that had an international appealing and influence hence the internationalisation of the conflict (Masunungure and Badza, 2010). Although the country managed to maintain relatively good diplomatic exchanges with the greater number of SADC member states, evidence of which is the insistence on an inter-party political solution to the conflict by the regional grouping, the conflict led to expressions of "impatience and apprehension especially in relation to economic decline and rising number of migrants from Zimbabwe. This has been the case of Botswana, South Africa and Zambia." (Zimbabwe Institute 2008, 19). Beyond SADC, the echoes of the conflict reached respective summits and security councils of the African union (AU) and the United Nations (UN) where the conflict in the country came under censure as a result of lobbying by both the opposition groups and CSOs involved in governance and human rights sector. The plummeting international approval rating married to domestic political dynamics led to inter-party dialogue that culminated in the formation of the inclusive government on 13 February 2009 which saw Zimbabwe's political rivalries working together under a de facto transitional arrangement necessitated by the Global Political Agreement (GPA) signed on 15 September 2008.

\section{The Church and Politics in Zimbabwe}

The fact that the church's influence is mainly on spiritual aspects does not stop church leaders from involvement in national politics. It is from this capacity that the church itself has spiritual programmes like church politics and administration (Russel, 2004). Based on the tenets of their beliefs, Christians in church and politics draw their inspiration to join national politics for diverse reasons. The reasons emanate from denominational doctrines, socialization, educational orientation, religious affiliation, political affiliation, personal attributes among other factors. Church leaders in the post-colonial Zimbabwe have towered 
head and shoulders over their contemporaries in many respects on the one hand. On the other hand, their reputations have also been soiled usually on moral grounds. The Zimbabwean community has had prominent religious figures like the late Reverend Canaan Sodindo Banana who was Zimbabwe`s first president after independence. Banana wrote many religious books like 'The church in Struggle for Zimbabwe' Turmoil and Tenacity: Zimbabwe 1890-1990 and also wrote books like "Rewriting the Bible." His reputation was tarnished when he was implicated in sodomy acts. Abel Muzorewa was another Zimbabwean cleric who at some point was the President of the short-lived Zimbabwe-Rhodesia in 1979 but lost the mantle of political glory to Robert Mugabe's in the landmark 1980 elections. Ndabaningi Sithole, a religious stalwart and founding president of ZANU also died a politician having established his party, ZANU Ndonga. This is significant to this study as it is crystal clear that religious leaders in Zimbabwe also play a pivotal role in shaping and influencing the national politics in Zimbabwe. At the turn of the new millennium, church leaders continued to influence the political discourse in Zimbabwe. United States Institute of Peace (USIP) (2003: 10) notes that "Zimbabwe is a deeply religious country and the churches are important social institutions". From the 1990s, the Catholic Church started now facing competition from the evangelicals in terms of membership and vitality. The USIP (ibid) notes that "the expanding membership and vitality of evangelical Christianity has somewhat eroded the catholic predominance and the Evangelical Fellowship of Zimbabwe (EFZ) has assumed new importance". Vocal catholic clerics, then, like Pius Ncube were even criticised by their "church hierarchies for vocal criticism of government and misuse of food aid" (USIP, 2003: 11). The government responded by exposing his alleged sexual scandal on national television and the press in 2008 .

With the production of the "Zimbabwe We Want" document, it is argued, that the church stood behind the birth of the GNU just like it opened the ground for effective multi-party politics towards the end of the $20^{\text {th }}$ Century. "The Zimbabwe We Want" chronicled "why Zimbabwe was suffering politically, socially and economically" (The Zimbabwe We Want, 2006: 7-11). The church "found a way out and was able to go to the people (70\% coverage of sampled population) except in three Mashonaland Provinces" (Muchechetere, 2009: 8). The outreach process sought to "elicit responses through a national exercise from the people as to how they would want to be governed and establish a new vision for Zimbabwe" (Muchechetere, 2009: 8). In as much as this step caused ZANU PF to treat the church`s document as regime change agenda, whilst the church views itself as a vehicle for reforms in a non-partisan manner. The role of the church was complimented with the will of the political parties and the involvement of the regional block, SADC in pushing for a political settlement in resolving the conflict. The power sharing pact was consummated on 15 September 2008 but its implementation began on 13 February 2009 when the executive was sworn into office. The power sharing pact has two distinguishable parts that were critical for the transition of the country to stability. The bulk of the GPA is occupied by the policy agenda while the remainder covers the framework of the IG. It is therefore important to locate church within this transitional period, specifically its role and impact in key processes such as nation-building and post-conflict reconstruction, constitution-making and in the preparations to the impending constitutional referendum and harmonised elections penned for the first half of 2013. 


\subsection{The Church and Nation-Building}

Representatives of Christian denominations have come up with collective decisions on political affairs in Zimbabwe. The millennium church has been very active in national affairs despite the mixed views from academics, critics, government officials and other sections of society. It is against this backdrop of taking collective decisions that the USIP (2003:10) "since 2000, the Zimbabwean churches have shown evidence of the same polarisation and politicisation as other sectors of society." The Crisis in Zimbabwe Coalition lauds the position by churches when they produced a position paper where it was noted that "Six church leaders led by EFZ President, Dr Goodwill Shana have produced a position paper entitled 'The Role of the Church in Nation Building in Zimbabwe' which they have taken to the region as a way to lobby for key reforms which are critical to Zimbabwe`s development" (Ibid). ZANU-PF considers the document as an "ill-informed document; and likened it to the position paper of the Movement for Democratic Change (MDC-T)" (USIP, 2003:10). The church continues to lobby for reform through their affiliate membership status to civil society organisations like National Constitutional Assembly (NCA). Dzinesu (2012: 2) notes that "the National Constitutional Assembly (NCA), formed in 1997 by a group of civic organisations that include churches, human rights groups, trade unions, women`s organisations, youth groups and student movements to press for a national charter, boycotted the COPAC process". It can be argued that the church has had an important role towards the turn of the millennium and is behind the birth of vibrant multi-party politics in Zimbabwe. This is because church leaders such as the late Ndabaningi Sithole formed breakaway opposition parties such as ZANU Ndonga and churches affiliated to movements like the NCA which supported opposition parties like the united MDC. This is the reason why it is argued that "non-state actors, including NGOs, trade unions, churches, private sector, academia, student movements and other stakeholders were unfortunately, not actively involved in the negotiation process (of the GPA)" (SADC-NGO, 2010: 2). Important issues can be addressed if these stakeholders, particularly the church, are allowed to be part of the GPA implementation mechanism. Betts and Kaytaz (2009: 15) note that "as of April 2009, there were around 3400 Zimbabweans living inside and outside the church". This alone is a gruesome indication of how the GNU is facing difficulties in satisfying neglected economic and social rights of its citizens. Churches have been crucial in complementing the government in ensuring that citizens access rights such as the right to shelter, food, health and education in the new constitution.

Representatives of various denominations have also engaged facilitators in the GPA. Some scholars like Tatira and Marevesa (2011) have even likened the GPA to the Jerusalem religious Council (CJ) of AD49 in trying to show that "both the GPA and the CJ tried to put people together who had different ideological orientation" (Tatira and Marevesa 2011: 19). National healing and reconciliation should not be left to politicians alone who may be bent on shielding their political parties. The Minister of Justice, Legal and Parliamentary affairs, Patrick Chinamasa indicated that perpetrators of 2008 political violence will not be prosecuted in the spirit of reconciliation. Machakanja (2010: 8) aptly notes that "national healing and reconciliation are embedded in moral obligations, the church or church-based 
individual organisations can claim moral authority and legitimacy to lead the National Healing and Reconciliation Process, as politicians are viewed as not having the moral integrity to remain neutral and/ or separate national issues from party political agendas". The dominant Christian networks like EFZ, ZCC and ZCBC advocate for reforms using through the Peace and Justice Commission (PJC) and the Church in Society (CIS)(Muchechetere 2009: 1). The three networks "observe and monitor elections, conduct voter education and civic education, advocacy against repressive legislation and any acts of conduct by government that violate people's civil liberties" (Muchechetere, 2009:1). This becomes important in ensuring that the GNU complies with international human rights instruments like the Covenant on Civil and Political Rights.

Churches have also been instrumental in the fight to stem political violence in Zimbabwe. Zimbabwean churches have also been part of the peace process in Zimbabwe. Zimbabwe Peace Project (ZPP), whose wide membership includes churches, lawyers, students, labour and women groups recorded an increase in rights violations and women activists on peaceful protests are arbitrarily detained and denied legal representation. The Legal Monitor (2012: 4) notes that "ZPP reported 462 human rights violations in August 2012, up from the 375 incidents recorded in July, mainly because of the constitutional impasse, the resurgence of ZANU PF aligned militias and the brutal crackdown by police and soldiers on commuter taxi ranks". This report is important because it shows the deterioration of the political environment in Zimbabwe considerably in August, a month before Zimbabwe commemorated the International Day of Peace. The report is fundamental as it shows victim analysis by affiliation with MDC-T having $60 \%$ of victims, ZANU PF $12 \%$ and MDC-N $0 \%$. The report shows that the church is also important in the GPA peace process since its members are not immune to violence. This augurs well with Lovemore Matombo's concern that "the church in Zimbabwe is both under attack from political forces, and is being used as a political entity in itself. However, the Christian community is beginning to organise itself as a means of protest against state violence and arbitrary state activity against the opposition" (ACTSA 2010: 5).

\subsection{The Church and the Constitution-making Process}

Representatives have also contributed to the contentious issues in the constitutional-making exercise currently obtaining in the GNU. The EFZ through its leader Goodwill Shana has indicated that it does not condone homosexual activities. Renowned radio preacher and Apostolic Faith Mission in Zimbabwe pastor, Reverend Happymore Gotora has also condemned the act as unbiblical. Churches like Zimbabwe Assemblies of God Africa (ZAOGA) have also utilised the media to condemn the activity. The issue of homosexual acts has been used by Kunonga as leverage against the Gandiya led Church of the Province of Africa mainly because of the church's links with the Church of England which has some bishops who have defended homosexuality as a fundamental right. This is albeit of the fact that no one from the Gandiya-led congregants has openly supported the activity. The dominance of Kunonga in Harare Province can best be explained in the way constitutional issues are handled by seemingly "orthodox" or conservative followers of the bishop who usually do not question the cleric. Due to the incessant opposition from the church, the first 
published draft of the new constitution excluded the right. This demonstrates the importance of the church in society as the custodians of moral values without whom the politicians could have been swayed by public opinion to entrench the unnatural right in the supreme law.

\subsection{The Church and Rule of Law}

The church has also been accused of interfering with the separation of powers in Zimbabwe. The Chief Justice of the Supreme Court of Zimbabwe warned Anglicans whose matters were before the courts to stop engaging the executive leadership on the matter. Nemukuyu (2012: 1) notes that the Chief Justice ordered that "all the matters relating to the above parties will be determined by the same court". Although the court is expected to determine the rightful owner of the Anglican property, the wrangle is an acid test on the church's role in politics within the GNU context. The Anglican Archbishop of Canterbury Rowen Williams is believed to have engaged President Mugabe during his visit to Zimbabwe in 2011. This did not deter the Church of the Province of Africa bishops from coming up with positions regarding sticky issues such as selective application of the law in the GNU environment. Bishops Cleopas Lunga (Matabeleland), Dr Julius Makoni (Manicaland), Dr Chad Gandiya (Harare), Godfrey Tawonezvi (Masvingo) and Ishmael Mukuwanda (Central Zimbabwe) came up with a position paper wherein they indicated that they are "disturbed that the police have taken sides... Why are they openly supporting the abuse perpetrated by Nobert Kunonga" (Lunga et al, 2012:1). Undeterred by the red line issued by the Supreme Court of Zimbabwe, the bishops registered their wish therein that "we are therefore appealing to President of the Republic of Zimbabwe, His Excellency President R. G Mugabe, members of the Government of National Unity, the co-ministers of Home Affairs and the Police Commissioner General to intervene in this matter where innocent and peace loving worshippers are being driven out of their church buildings for no legitimate reason" (Lunga et al, 2012:1). The sentiments of the bishops hold since the police were driving people in Chivhu which falls out of the jurisdiction of Harare Province where the property wrangle spilled into the courts. The church continues to fight for recognition in the GNU as it appears that the visit by the Anglican leader Archbishop Williams yielded nothing in terms of uniting the divided church in Zimbabwe.

\subsection{The Church and the Impending Elections}

The indigenous churches like the white garment churches have been accused of supporting ZANU-PF. The churches that have courted controversy include Johanne Masowe and Johanne Marange. The ZANU PF leadership has frequently fellowshipped with the two indigenous churches whose membership is scattered around the country. The ZANU PF politburo members have also been part of the religious visits and this has been seen as a step towards winning the votes from the usually conservative sect members. The Johanne Masowe weChishanu in particular have openly supported ZANU PF, particularly during the last days of the late Madzibaba Nzira. Even opposition leaders like Mr. Tsvangirai, who is also the Prime Minister in the GNU have removed their shoes to join the Marange followers in worship. This may be a deliberate ploy by the two dominant political parties to infiltrate or manipulate the populous worshippers into supporting them. Some indigenous church leaders like Paul Mwazha of African Apostolic Faith Church have maintained a low profile in the 
GNU. Mwazha condemned sanctions just like other church leaders like Kunonga and Makandiwa. Prophet Makandiwa signed the Anti-Sanction Petition that was the brainchild of ZANU PF. The petition saw the European Union (EU) removing some of the individuals like Senator Georgias. The EU is also engaging Zimbabwe through representatives of the political parties and the role of the church in this regard cannot be underestimated.

Ex-communicated Bishop Dr Nobert Kunonga "openly stated that he was a proud recipient of land through the government Land Reform Program and openly supported ZANU (PF)" (Muchechetere, 2009: 14). Other mainline church bishops who have brazenly shown their partisanship include "Bishop Levy Kadenge a former Methodist Church in Zimbabwe Bishop who was also chided by his church leadership for openly supporting the opposition" (Muchechetere, 2009: 14). Bishop Dube "former head of the United Baptist Church and former governor of Manicaland under ZANU (PF) was also partisan and a fierce critic of opposition politics" (Muchechetere, 2009: 14). The family of God Church led by Prophet Andrew Wutawunashe has been accused of forming "Faith For the Nation" that "articulated the policies of ZANU (PF) and openly opposed, even in the media any church leadership that sought to sanction the ruling party and government as in the June 2008 elections" (Muchechetere, 2009: 14).

The church has been used as a platform for political glorification. The Herald of 3 October (2012: 2) carried a story where ZANU-PF politiburo member Tendai Savanhu donated groceries to 51 households made up of the elderly, people living with HIV and AIDS, orphans and the vulnerable living at Matapi Hostels in Mbare. Laudable as this move might be, the politician was in the company of Pastor Alwyn Bizure of Adonai Ministries as he moved into each household. The man of the robe commended "Cde Savanhu and ZANU-PF leadership in Mbare for putting God's word into practice by assisting the disadvantaged groups in society". The man of the cloth went on to say that "this gesture by Cde Savanhu shows ZANU PF has God-fearing leadership that are obedient and visionary" (Herald, 2012:2). It can be argued since the church leaders wield influence over their followers the politicians find it easy to exploit this comparative advantage for cheap political scores hence the recipients can be easily swayed by the remarks from the man of the cloth and can be influenced in their choices in the constitutional referendum and most importantly the elections that are likely to be held in March 2013. Religious leaders may be more social savvy than their flocks or those who look up to them as men of God. The glorification of one party by a man of the cloth may send wrong signals to the other parties in the GNU and augurs well with the sentiments of opposition functionaries referred to above that churches should not claim to be apolitical when they are not. It is easy for religious leaders to be used as pawns in the much bigger chess game.

\section{Conclusion and Recommendations}

The paper has attempted to establish the relationship between the church and the state in Zimbabwe within the transitional framework. Evidence collated indicates that religion and politics are interwoven and have been so since the medieval era when political thinkers such as St Augustine and St Aquinas attempted to theorise on the subject. The church is an 
instrumental unit in influencing government policy albeit in some instances its influence sometimes suffers from the culture of political exclusion. This is hardly surprising since the church is part of the civil society organisations which have had a bumpy relationship with the government whenever they attempt to query its decisions or actions.

The article recommends that since the church and the state presents two sides of the same social reality, the church should be active in partaking in public policy which has an impact on the well-being of the parishioners. It is further suggested that politics is something natural to men and his development hence political activity is something that the church should all the time regard in the positive.

\section{References}

ACTSA, (2010) “Zimbabwe 30 years on: Rights Challenges and Opportunities: ACTSA

Adam, I \& Dyson. R.W. Fifty Major Political thinkers. London: Routledge, 2007.

AfroBarometer. 2006. People's development agenda and government's policy performance in Zimbabwe. Afrobarometer Briefing Paper no.27: Harare.

Betts, A and Kaytaz, E (2009) New Issues in Refugee Research: National and International Responses to the Zimbabwean: Implications for the Refugee Protection" Research Paper No. 175, Oxford University.

Boucher, D and Kelly, P (eds) (2009). Political Thinkers: From Socrates to the Presen $\left(2^{\text {nd }}\right.$ ed),. Oxford: Oxford University Council.

Bratton, M and Masunungure, E. 2012. The anatomy of political predation: Leaders, elites and coalitions in Zimbabwe 1980-2010 http://www.dlprog.org/.../The \% 20 Anatomy\%20of\%20Predation.(accessed November 12.2012).

Chimhini D, et al (2008) “Whither Zimbabwe: Government of National Unity or Transitional Government” New Ambassador Hotel: Harare

Commonwealth Observer Group. 2000. The parliamentary elections in Zimbabwe: Report of the Commonwealth observer group. London.

Common Weath Observer Group.2002.Zimbabwe presidential election. March 2002: Report of the commonwealth observe group. London

Crisis in Zimbabwe Coalition (2011), "Persecution of NGOs, ZANU PF Election Strategy", Crisis in Zimbabwe Coalition, Harare.

Churches of Zimbabwe (ZCC, EFZ, ZCBC) (2006) "The Zimbabwe We Want: Towards a National Vision for Zimbabwe" Bernaby Printing and Publishers, Harare.

Dzinesu, A. G (2012) “Situations Report” Institute for Security Studies

Herald Reporter, "Savanhu donates to the elderly" The Herald 3 October 2012, Harare.

Lunga, C eta al (2012) "Continued Harassment of Anglican Church Members in the Anglican 
Diocese of Masvingo in the Church of the Province of Central Africa”, Harare.

Machakanja, P (2010) "National Healing and Reconciliation in Zimbabwe: Challenges and Opportunities" Institute for Justice and Reconciliation, Africa Programme, Zimbabwe Monograph Series, No. 1

Makumbe, J. (2011), “What is the Global Political Agreement?" SITO. Also available at http://www.statesintransition,org? (accessed October 10, 2012)

Makumbe, J. Theft by numbers: ZEC's role in the 2008 elections http://www.kas.de/upload/documente//2010/05/Defying-7.pdf (accessed November 12,2012).

Masunungure,E.V.ed.2009.Defying the winds of change. Harare: Weaver Press.

Masunungure, E,V.2011. Zimbabwe's militarized electoral authoritarianism. Journal of international affairs 65.no.1:47-68.

Masunungure and Badza, S. 2010. The internationalization of Zimbabwe's crisis: Multiple actors, competing interests. Journal of developing societies 26, no.2:207-

Media Institute of Southern Africa. Graves for victims of political violence. http://www.thezimbabwean.co.uk/new/36118/graves-for-victims-of-political-violence.html (accessed November 12.2012).

Muchechetere, A. A (2009) "a Historical Analysis of the Role of the Church in Advocating foe Good Governance in Zimbabwe: Heads of Christian Denominations (HOCD) Advocating in Zimbabwe`s Political, Social AND Economic Impasse from 2003 to 2008”, ALMA, Harare (unpublished dissertation)

Nemukuyu, D. (2012) “Supreme Court to Decide On Anglican Row This Month", The Herald I October 2012, Harare.

Nyamandebvu, M. (2010) "Joburg School Closure adds to Anxiety" in Crisis in Zimbabwe Coalition (2010) "From National Unity to Parallel Government: Understanding Zimbabwe towards 2011" Zimbabwe Briefing: Crisis in Zimbabwe Coalition Regional Office-Weekly Report, Issue 2

Pasura, D Zimbabwe migrants in Britian: An overview http://www.migrationeducation.de/49.1html (accessed November 12.2012)

Raftopoulos. B. and Savage. T. 2005. Zimbabwe: Injustice and political reconcialition Harare:Weaver press.

Russel, R (2004) "Church Education Systems Politics and Administration”, Latter Day, Lampton

Sachikonye L. M. ed.1995. Democracy, civil society and the state. Harare: Sapes books.

Sachikonye, L. M.et. Al.2007. Consolidating democracy in Southern Africa: The case of Zimbabwe. Johannesburg:EISA. 


\section{Macrothink}

Journal of Public Administration and Governance ISSN 2161-7104 2013, Vol. 3, No. 1

SADC-CNGO (2010) "High-level National Policy Dialogue: Taking Stock, Exploring New Directions and Rethinking the Future of Zimbabwe", SADC-CNGO.

SAPA-AFP (2008) Zimbabwean Church Leaders Urge Action” SAPA-AFP (IOL)

Solidarity Peace Trust (2008) "Punishing Dissent, Silencing Citizens: The Zimbabwean Eletions 2008" Solidarity Peace Trust, Johannesburg.

Tatira, L. Marevesa, T (2011) "The Global Political Agreement (GPA) and the Persistent Political Conflict Arising there from: Is this another Manifestation of the Council of Jerusalem?" Journal of African Studies and Development Vol. 3(10) pp187-191, available http://www.academicarticles.org/JASD accessed 20 September 2012.

The Legal Monitor (2012) "Zim's sad Peace Day, GPA anniversary: clock turning back to 2008 era", Edition 162, Zimbabwe Lawyers for Human Rights: Harare.

Tibaijuka ,A.K (2005) "Report of the Fact-Finding Mission to Zimbabwe to Assess the Scope and Impact of Operation Murambatsvina" UN Special Envoy of Human Settlement Issues in Zimbabwe, New York.

United States Institute of Peace (2003) "Zimbabwe`s Torturous Road to a New Constitution and Elections" Special Report, Washington DC, I09, also available http://www.usip.org accessed 12 September 2012. 